\title{
HETEROGENITAS ORANG KETURUNAN CINA (TIONGHOA) DI INDONESIA DALAM PERSPEKTIF SOSIAL-BUDAYA
}

\author{
Thung Ju Lan
}

\begin{abstract}
Abstrak
Masalah heterogenitas orang Tionghoa Indonesia seringkali dilihat sebagai sesuatu yang sederhana, karena cara pandang yang umum cenderung terfokus pada katagorisasi tradisional, seperti suku bangsa, agama dan pekerjaan. Padahal, perkembangan masyarakat yang didukung perkembangan teknologi pada prakteknya telah memunculkan variabel 'kelas' dan 'pengaruh global' yang mendiversifikasi berbagai kegiatan sosial-ekonomi sehingga secara keseluruhan dunia usaha dan dunia kehidupan 'lokal' dan/atau 'nasional' menjadi sangat kompleks. Dengan demikian, keberagaman orang Tionghoa di Indonesia juga, tidak saja harus dilihat melalui katagorisasi tradisional, melainkan juga berdasarkan sejarah politik negara-bangsa Indonesia sendiri, dinamika hubungan antara negara asal orang Tionghoa (negara Cina) dengan negara tempat orang Tionghoa bertempat tinggal (Indonesia), persebaran orang Tionghoa di wilayah Indonesia yang terdiri sejumlah pulau besar dan kecil, serta pandangan individu etnis Tionghoa yang berbeda tentang bagaimana menempatkan orang Tionghoa di dalam masyarakat Indonesia.
\end{abstract}

\section{Kata Kunci}

\begin{abstract}
The issue of heterogeneity of Chinese Indonesians is often seen as something simple, because the general view tends to focus on traditional categorization such as race/ethnic group, religion and occupation. In fact, the development of the society which was supported by technological development has produced the variable of 'class' and global influences that diversify various social and economic activities so that the world of business and life within the 'local' and/or 'national' realms as a whole becomes very complex. As a result, the heterogeneity of Chinese Indonesians should be seen, not only through traditional categorization, but also according to the political history of Indonesian nation-state, the dynamics of relations between China, as the country of origin, and Indonesia as the country of settlement, the scattering of Chinese in Indonesian territory that consists of a number of big and small islands, as well as the Chinese individual's perspective on how the Chinese should be located in the Indonesian society.
\end{abstract}

\section{Keywords}




\section{PENDAHULUAN}

Pembicaraan tentang heterogenitas komunitas Cina (Tionghoa) di Indonesia pada umumnya akan dikaitkan dengan pembagian suku-suku yang dikenal di negara Cina, seperti suku Khe (Hakka), suku Hokkian, suku Teochiu, dan suku Hokchia, yang tentu saja dilengkapi dengan sejarah migrasi orang Cina (Tionghoa) ke Indonesia. Akan tetapi, di dalam tulisan ini saya ingin menunjukkan bahwa heterogenitas orang Cina di Indonesia jauh lebih kompleks daripada jika hanya dilihat berdasarkan pengklasifikasian atas dasar asal-usul atau kesukuan di atas.

Seperti kita ketahui, orang Tionghoa di Indonesia dianggap 'bukan orang Indonesia asli' karena, pertama, asal-usulnya tadi yang berasal dari negara Cina/Tiongkok, dan kedua, adanya anggapan bahwa setiap 'orang Indonesia asli' berasal dari salah satu suku yang dikenal/diketahui mempunyai 'kampung halaman' di bumi Nusantara, baik berupa sebuah pulau, ataupun bagian dari sebuah pulau, seperti orang Minangkabau dan orang Batak dari pulau Sumatera, orang Sunda dan Jawa dari pulau Jawa, orang Dayak dari pulau Kalimantan, orang Ambon atau Maluku dari Kepulauan Maluku, dan orang Papua dari pulau Papua. Dalam perspektif ini, orang Tionghoa tidak termasuk salah satu suku tersebut karena tidak memiliki 'kampung halaman di Indonesia'.

Pandangan tentang asal-usul orang Cina yang dikembalikan ke negara Cina/ Tiongkok dan pandangan tentang keaslian orang Indonesia yang dikaitkan dengan keberadaan kampung halaman mereka di bumi Nusantara pada dasarnya merupakan satu hal yang sama, yaitu menganggap setiap komunitas manusia mempunyai daerah asal yang selanjutnya menjadi wilayah budaya dari komunitas yang bersangkutan. Pandangan semacam ini walaupun sangat problematik, namun sepertinya diyakini oleh tidak saja oleh kalangan awam, melainkan juga oleh kalangan akademisi di Indonesia. Oleh sebab itu, seperti kita ketahui, Undang-undang Dasar 1945 menetapkan bahwa Presiden Republik Indonesia harus 'orang Indonesia asli'. Walaupun pasal yang memuat hal itu sudah dirubah dalam Undang-undang Dasar yang diamandemen, akan tetapi tidak berarti bahwa pandangan semacam itu dengan sendirinya sudah tidak ada. Menarik untuk mencermati kutipan berikut ini:

\footnotetext{
"Violence and discrimination against the Chinese in Indonesia has become the normal course of events. It has been so normal that the Chinese themselves seem to accept it as a given thing, the inevitable consequence of being a minority. 'That is already our fate!' was a standard answer when I asked why they kept silent, or only grumbled in the back ground whenever they were unfairly treated or attacked. 'What could we do? They are the owners of this land, while we just live on their land making a living (kita hanya numpang hidup dan cari makan di sini)' (Susanto, 2001:183).
}

Perspektif tentang asal-usul atau kampung halaman ini pada hakekatnya telah menempatkan orang Cina-Indonesia pada posisi di antara tanah leluhur (Tiongkok) dan negara tempat mereka bermukim (Indonesia). Dalam pertemuan pertama saya 
dengan Profesor Jamie Mackie di tahun 1990an, beliau memakai istilah 'pendulum'. Menurut Mackie, orang Cina-Indonesia selalu berada dalam hubungan tarik-menarik dengan tanah leluhurnya di negara Cina/Tiongkok dan dengan negara dimana mereka sekarang tinggal/bermukim, yaitu Indonesia, sebagaimana pendulum pada lonceng yang selalu digoyang dari ujung kanan ke kiri dan kembali ke ujung kanan lagi. Kondisi tersebut adalah salah satu variabel penting yang perlu kita bahas di sini untuk melihat heterogenitas orang Cina (Tionghoa) di Indonesia.

Variabel lainnya adalah persebaran orang Tionghoa di wilayah Indonesia yang terdiri dari sejumlah pulau besar dan kecil, dan dihuni oleh 'penduduk asli' yang, sebagaimana telah disinggung di atas, berbeda-beda suku dan kebudayaannya dari satu ke tempat lainnya. Keberadaan beragam suku di Nusantara yang berbeda budaya pada prakteknya memberikan pengaruh yang berbeda pula pada interaksi sosial antara orang Tionghoa yang bermigrasi ke satu wilayah, misalnya di pulau Sumatera, dan mereka yang bermigrasi ke daerah lainnya, seperti kepulauan Maluku. Keberagaman konteks sosial inilah yang ingin penulis bahas di sini.

Selain dua variabel di atas, kita juga perlu melihat variabel pekerjaan atau profesi yang banyak ditekuni oleh komunitas Tionghoa di Indonesia, di masa lalu maupun di masa kini, karena melalui pekerjaan, yang sering disebut juga sebagai mata pencaharian, interaksi antar suku, termasuk interaksi antara orang Cina (Tionghoa) Indonesia dengan suku-suku yang ada di bumi Nusantara pada umumnya berlangsung.

Terakhir, penting pula untuk memperhatikan perubahan yang terjadi dari generasi ke generasi, karena sebagaimana kita ketahui, perubahan zaman yang diikuti dengan kemajuan teknologi membawa perubahan kepada setiap masyarakat yang ada di dunia ini, baik pada struktur sosial maupun nilai-nilai budaya yang dimilikinya.

\section{'TOTOK' DAN 'PERANAKAN': ORANG CINA-INDONESIA DI ANTARA 'NEGERI ASAL' DAN 'NEGARA TEMPAT BERMUKIM'}

Persoalan ini sudah dikemukakan oleh banyak peneliti asing yang mempunyai perhatian khusus terhadap kehidupan etnis Cina di Indonesia. Salah satu di antaranya adalah Profesor J.A .C. Mackie. Menurut Mackie, "[t]he state of Indonesia's relations with China has been an important background factor influencing the political dispositions of the Indonesian Chinese and the intensity of the the pressures to which they have been subjected, although there is no simple correlation between these variables" (1976:16, italic ditambahkan). Hal ini diperkuat oleh Profesor Wang Gungwu yang mengatakan bahwa, "[a]....comparison may be made for the 'nationalist' pattern, where politics was primarily the extension of China politics.....Here was a pattern partly rooted in the Chinese communities themselves and partly directed and moulded by politicians, government officials, educators and journalists from China. Throughout this century, we can observe in every country in the [Southeast Asia] region traditional, colonial and nationalist governments trying to intervene to break the tensions created between the Chinese overseas and 
their mentors in China. Some governments have been more successful than others in containing such political activities" (1976:201, italic ditambahkan). Artinya, hubungan budaya dan politik dengan negara Cina/Tiongkok sebagai 'tanah leluhur' dapat berdampak pada hubungan komunitas Cina/Tionghoa dengan negara di mana mereka tinggal, dalam hal ini Indonesia, sama seperti hubungan antar-negara antara Tiongkok dengan Indonesia dapat berdampak pada komunitas Tionghoa di Indonesia.

Selanjutnya juga dikatakan bahwa "[w]here the Chinese exercised their initiatives, the different reactions of various governments and various indigenous leaders created totally different conditions for the Chinese to live and act in... [T]he Chinese found themselves being hemmed in by different and often unexpected laws and measures which were increasingly to differentiate the levels of political activity at which they could operate as Chinese" (Wang, 1976:202, italic ditambahkan). Walaupun pendapat Wang ini dimaksudkan untuk melihat persamaan dan perbedaan komunitas Tionghoa di Indonesia dengan negara-negara lain di Asia Tenggara, akan tetapi apa yang dipaparkannya itu pada hakekatnya memperlihatkan bahwa lingkungan politis (dan tentu saja lingkungan budaya) di negara di mana komunitas Tionghoa bertempat tinggal, misalnya di Indonesia, memberikan pengaruh yang bersifat spesifik-lokal kepada komunitas Tionghoa yang bersangkutan.

Perbandingan pada tingkat negara ini, sayangnya mengabaikan fakta bahwa di dalam setiap negara pun masih ada variasi lagi. Seperti dikemukakan oleh Mackie dan Coppel (1976:5-6), "[t]he many Chinese communities scattered throughout the [Indonesian] archipelago have differed from one another in many ways - by reason of their length of settlement, the languages and occupations of the settlers and the degree of isolation of one community from another, as well as differences related to the culture and relative size of the indigenous societies among which they settled" (italic ditambahkan). Sejalan dengan pendapat Mackie ini, kita memang sudah bisa menemukan adanya pembedaan antara 'totok' dan 'peranakan' di kalangan orang Tionghoa di Indonesia. Pengklasifikasian ini sudah tampak, antara lain, dalam buku yang diedit Leo Suryadinata yang berjudul Political Thinking of the Indonesian Chinese, 1900-1995, a sourcebook (Singapore University Press, 1979). Seperti dijelaskan oleh Mackie dan Coppel, "totoks (literally, 'of pureblood')" adalah "those who had recently immigrated, spoke Chinese and were culturally oriented towards China", sementara "peranakan", yang jauh lebih tua, dikarakterisasikan "by the use of the vernacular language for everyday purposes and by a distinctive set of cultural traits which were neither wholly Chinese nor wholly Indonesian" (1976:5, italic ditambahkan).

Bertolak dari pembedaan ini, kita melihat munculnya pandangan yang berbeda yang berlanjut menjadi perdebatan berkepanjangan tentang bagaimana menempatkan orang Tionghoa di dalam masyarakat Indonesia. Perbedaan pandangan ini adalah apa yang kita kenal sebagai 'asimilasi versus integrasi', sebagaimana dibukukan oleh $\mathrm{H}$. 
Junus Jahja ${ }^{1}$. Menurut Jahja,

\begin{abstract}
"Paham asimilasi atau pembauran mengharapkan agar 'Indonesia keturunan Tionghoa' sebagai individu (bukan sebagai golongan) dengan suku setempat (kalau di Minahasa dengan suku Manado, kalau di Solo dengan suku Jawa) saling mendekati di segala lapangan: politik, ekonomi, kebudayaan, olahraga, sosial, keluarga. Dengan satu kata singkat: asimilasi/pembauran. Jadi mereka langsung menyebar di kalangan rakyat banyak yakni suku-suku yang sudah ada. Dan kemudian, sesuai Sumpah Pemuda 1928 kita bersama-sama menuju 'manusia Indonesia Raya'. Untuk itu perbedaan dengan mayoritas penduduk jangan terlalu mencolok, tetapi dikurangi. Sebab hanya dengan demikian keturunan Tionghoa lebih mudah diterima di kalangan rakyat banyak di tingkat akar-rumput (grassroots) sebagai 'orang kita' dan bukan hanya di lingkungan tertentu yang terbatas saja..." (1999: i-ii, italic sebagaimana teks aslinya).
\end{abstract}

Jelas bahwa pandangan di atas dikeluarkan oleh seorang 'peranakan', seperti Junus Jahja, yang melihat dirinya 'dilahirkan di sini', dan 'menekankan persamaan dengan masyarakat mayoritet Indonesia' (1999:9²). Di sisi lain, ada kelompok lain yang oleh Junus Jahja dikatakan sebagai berpegang pada 'terapi integrasi'. Menurut Jahja,

\begin{abstract}
"Integrasi secara harfiah berarti 'menyatukan, menggabungkan'. Tapi 'terapi integrasi' hanya ingin menyatu dengan sejumlah 'persyaratan'. Mereka ingin mempertahankan etnik Tionghoa (walaupun sudah Warganegara RI) sebagai golongan 'minoritas' (yang berbeda dengan mayoritas), menuntut diakuinya sebagai suku (yang sederajat dengan suku Jawa, Sunda, dan lain-lain). Jadi terapi 'integrasi' di bawah Baperki (Badan permusyawaratan Kewarganegaraan Indonesia) pimpinan almarhum Siauw Giok Tjhan hanya ingin menyatu sebagai 'suku' atau kelompok tersendiri (separate but equal) sambil mempertahankan ciri-ciri ke-Tionghoa-annya (Chineseness) dengan eksklusivisme-seketurunannya dalam kehidupan sehari-hari sebagai konsekuensi logisnya" (1999:ii, italic sebagaimana teks aslinya).
\end{abstract}

Untuk keseimbangan, ada baiknya jika kita mendengarkan juga pendapat Siauw Giok Tjhan tentang hal ini. Menurut Siauw,

"Patut juga diperhatikan bersama, bahwa penggunaan istilah 'asimilasi' yang diartikan peleburan
total, dalam pengalaman ternyata dapat menimbulkan pikiran-pikiran tambahan yang sering
kali mendorong ke arah memaksakan dipercepatnya proses peleburan total untuk melenyapkan
perbedaan-perbedaan ciri-ciri ethnis (suku), kebudayaan, agama dan lain-lainnya yang justeru
tidak dikehendaki oleh para penganjur penggunaan istilah asimilasi itu sendiri. Pengalaman ini
menimbulkan pertimbangan untuk menggunakan istilah 'integrasi' dalam arti mencapai kesatuan
harmonis, seperti macam-macam bunga dalam karangan bunga sesuai dengan lambang negara kita
'Bhinneka Tunggal Ika', yang mengakibatkan kesediaan (kemauan) pada tiap orang warganegara
tidak memandang asal keturunan apa dan suku apa, untuk hidup, bekerja dan berjuang ke arah

1 Jahja, H. Junus, 1999, Masalah Tionghoa di Indonesia: Asimilasi vs Integrasi, Jakarta: Lembaga Pengkajian Masalah Pembauran. Perlu dicatat bahwa meskipun judulnya adalah 'asimilasi versus integrasi', akan tetapi buku ini pada hakekatnya lebih banyak menekankan pada pendekatan asimilasi sebagaimana yang diyakini oleh Junus Jahja sendiri.

2 Dalam tulisan berjudul “Warganegara Tunggal (I)” (Tajuk Star Weekly, 13 Februari 1960) yang diterbitkan kembali oleh H. Junus Jahja (1990) dengan judul Masalah Tionghoa di Indonesia: Asimilasi vs Integrasi, hal. $5-11$. 
diperkokohnya perasaan senasib dan sepenanggungan jawab, yang menyebabkan mereka sebagai satu kesatuan yang harmonis sanggup mengatasi segala krisis penghidupan dengan tekad bulat dan memperkokoh keamanan kehidupan nasionalnya, kehidupan sebagai bangsa yang merdeka dan berdaulat penuh" (Jahja, 1990:473).

Pandangan Siauw ini sulit dikatakan sebagai pandangan seorang 'totok', akan tetapi 'terapi integrasi' yang diusulkannya itu memang sepertinya mempertimbangkan posisi orang Tionghoa 'totok' yang tentu saja akan mengalami lebih banyak kesulitan dalam melakukan 'peleburan total' dibanding kelompok 'peranakan'. Perbedaan pendapat ini masih tampak sampai hari ini. Misalnya saja, jika kita mengamati dua organisasi massa orang Tionghoa yang ada pada hari ini, yaitu Perhimpunan INTI (Indonesia Tionghoa) dan PSMTI (Paguyuban Sosial Marga Tionghoa Indonesia), maka akan tampak bahwa dua pendekatan tersebut - asimilasi dan integrasi - masih membayangi dan membedakan warga Tionghoa sehingga menjadi dua kelompok tersebut; walaupun perbedaan di masa kini tidak sekeras perbedaan di masa lalu. Jika kita mengamati kegiatan-kegiatannya, nampak bahwa Perhimpunan INTI lebih menekankan berbagai upaya agar orang Tionghoa 'diterima' sebagai bagian dari masyarakat Indonesia, baik melalui 'program Bakti Sosial Pengobatan Massal' maupun seminar-seminar bertemakan isu-isu kesehatan dan politik. Sementara PSMTI lebih menekankan pada pemeliharaan dan pengakuan terhadap budaya Tionghoa, khususnya melalui pembangunan Anjung Tionghoa di Taman Mini Indonesia Indah (TMII) yang sampai hari ini masih belum rampung.

Sulit untuk mengatakan bahwa seluruh anggota Perhimpunan INTI adalah 'peranakan'. Begitu juga terhadap anggota PSMTI, kita tidak bisa mengatakan bahwa mereka semua adalah 'totok'. Tidak ada batasan yang jelas tentang siapa 'peranakan' atau siapa 'totok' untuk konteks hari ini, akan tetapi pembagian ini sepertinya masih cukup signifikan untuk diperhitungkan dalam melihat heterogenitas orang Tionghoa saat ini, karena pemaknaan secara sosial-budaya terhadap pendikotomian tersebut tidak akan pernah hilang selama ia dikaitkan dengan pola hubungan orang Tionghoa Indonesia dengan negara asal (Cina/Tiongkok) dan dengan negara tempat tinggalnya (Indonesia). Jika kita kembalikan ke perdebatan soal asimilasi dan integrasi, maka persoalannya akan semakin jelas. Bahwa jika secara budaya lebih dekat kepada negara asal (Cina/Tiongkok), maka yang bersangkutan bisa dikatakan sebagai 'totok', sementara yang lebih dekat secara budaya kepada negara tempat tinggal (Indonesia) cenderung disebut sebagai 'peranakan'. Pandangan linear seperti ini memang problematik, akan tetapi cukup dominan, baik di kalangan Tionghoa sendiri maupun di kalangan non-Tionghoa di Indonesia.

\footnotetext{
${ }^{3}$ Dalam tulisan Siauw Giok Tjhan yang berjudul "Mempercepat Terwujudnya Masyarakat Adil \& Makmur" (Star Weekly, 2 April 1960). Tulisan ini menjadi bagian dari buku Junus Jahja (1999) yang berjudul Masalah Tionghoa di Indonesia: Asimilasi vs Integrasi, hal. 46-47.
} 


\section{ORANG CINA-MEDAN, ORANG CINA-PONTIANAK, ORANG CINA-JAWA, DAN SETERUSNYA: PERSEBARAN \& 'LOKALISASI' ORANG TIONGHOA DI NUSANTARA}

Jika pada tingkat internasional kita bisa berbicara tentang keberadaan 'the Chinese Diaspora' ${ }^{4}$ yang pada prinsipnya terkait dengan konsep 'growing roots where they land' atau luodi shenggen ${ }^{5}$ (dengan contoh Malaysian Chinese, Indonesian Chinese, Singaporean Chinese, American Chinese, dan sebagainya), sesungguhnya kita bisa memakainya pula dalam konteks keIndonesiaan yang wilayahnya dan masyarakatnya terbagi atas pulau-pulau dan suku-suku yang beraneka ragam. Misalnya saja kita menemukan adanya sebutan Cina Sumatera, Cina Kalimantan, Cina Sulawesi dan sebagainya. Selain itu sering pula kita dengar sebutan-sebutan tentang Cina-Medan, Cina-Jakarta, Cina-Pontianak, CinaManado, Cina-Jawa, Cina-Singkawang, Cina-Makasar, dan seterusnya. Munculnya varian-varian orang Cina (Tionghoa) berdasarkan nama kota atau wilayah tempat tinggalnya ini bisa dikatakan sebagai hasil dari proses persebaran dan proses 'lokalisasi' mereka di kepulauan Nusantara atau Indonesia.

Proses lokalisasi ini tidak bisa dilepaskan dari proses akulturasi dan asimilasi yang terjadi selama beberapa generasi. Oleh sebab itu, terkait dengan diskusi kita sebelumnya tentang 'peranakan' dan 'totok', pada dasarnya kita juga dapat menyamakan konsep luodi shenggen ini dengan proses asimilasi yang menghasilkan 'peranakan'. Seperti dijelaskan oleh Wang Ling-Chi, "[t]he luodi shenggen approach .... views the Chinese minority to be an integral part of each country's citizenry, to be treated with equality and justice" ${ }^{\prime \prime}$. Akan tetapi, jika kita mengikuti pendapatnya selanjutnya, bahwa "[t]his approach also posits the racial and cultural heritage of the Chinese and treats the overseas Chinese as a cultural asset in the building of more enlightened societies in our integrated global economy and shrinking world, whose diversity is brought ever closer home by expanding international trade, rapid flow of information, capital and labour across national boundaries and jet-age travel" bahwa konsep luodi shenggen juga mencakup kelompok 'totok'. Padahal, di masa lalu, 'totok' dianggap lebih dekat pada konsep luoye guigen yang berarti 'return to their roots' 8

\footnotetext{
4 Menurut J.L. Heilbron, kata 'diaspora' yang berasal dari kata Yunani 'dispersion' pertama kali dipergunakan dalam penterjemahan Injil ke dalam bahasa Yunani yang dilakukan oleh orang Yahudi di Alexandria, meskipun menurut pendapatnya, kata Hebrew yang diterjemahakan menjadi kata 'diaspora' mempunyai arti yang lebih dekat dengan kata 'exile'; barangkali ini terkait dengan fakta bahwa "many Jews were forcibly removed to Babylon and kept there against their will, as an exile" (2003:xii). Dalam hal 'Chinese diasporas', Hebron berpendapat bahwa mereka lebih mendekati 'the Jewish diaspora', karena "[ $t$ ]hey have been quasi-enslaved as coolie labourers; they have been sojourners in foreign lands, voluntary exiles eager for repatriation" (Ibid., hal. xiv).

5 Wang Ling-Chi \& Wang Gungwu (2003), "Preface”, dalam Wang Ling-Chi \& Wang Gungwu (eds.), The Chinese Diaspora: Selected Essays, Volume II, Singapore: Eastern University Press, hal. vi.

6 Wang Ling-Chi, 2003, “On Luodi-shenggen”, dalam Wang Ling-Chi \& Wang Gungwu (eds.), The Chinese Diaspora: Selected Essays, Volume II, Singapore: Eastern University Press, hal. x.

7 Ibid.

8 Wang Ling-Chi \& Wang Gungwu, Opcit., hal. vii.
} 
karena kecenderungan mereka yang selalu kembali ke China/Tiongkok, baik secara fisik (huaqiao - Chinese sojourners - Cina perantauan) maupun dari segi orientasi budaya dan politik (haiwai huaren - Chinese overseas). Sepertinya, sebagaimana telah dikemukakan di bagian sebelumnya, sudah sulit menetapkan batas antara 'totok' dan 'peranakan' dalam konteks kehidupan modern hari ini. Jika Wang Ling-Chi mengkaitkannya dengan proses globalisasi, penulis cenderung melihatnya sebagai hasil dari proses konsolidasi negarabangsa yang, dalam konsep Barat, disebut nation-state.

Jika konsep luodi shenggen tersebut ditarik ke tingkat lokal, barangkali di masa depan kita sudah harus berbicara tentang kaitan antara etnisitas, dan lingkungan sosialgeografis dalam membentuk komunitas-komunitas heterogen, termasuk komunitaskomunitas Cina (Tionghoa) pada tingkat pulau, provinsi, kabupaten, kecamatan, dan desa di Indonesia. Untuk lebih jelasnya kita akan berbicara tentang orang Cina (peranakan) Makasar. Hasil penelitian Shaifuddin Bahrum (2003) memperlihatkan bahwa "dalam pola kehidupan sosial dan kebudayaan Makassar dapat ditemukan unsurunsur kebudayaan Cina. Sebaliknya, dalam kehidupan orang Cina pun di Makassar, terutama orang Cina Peranakan, juga dapat ditemukan unsur-unsur kebudayaan Makassar yang sudah membaur" (hal.73). Misalnya, dalam hal istilah kekerabatan orang Cina Peranakan Makassar dapat ditemukan beberapa istilah yang sangat dekat dengan istilah Makassar. Misalnya, saudara laki-laki adik ego, baik dalam istilah Makassar maupun istilah Cina Peranakan Makassar disebut Sariqbattang Buragne (Andiq); begitu pula dengan saudara perempuan adik ego yang disebut sebagai Sarigbattang Baine (Andiq) dalam istilah Makassar maupun istilah Cina Peranakan Makassar. Contoh lainnya adalah adik dekat ego yang disebut Andiq dan adik bungu yang disebut Andiq Bungko, atau sepupu satu kali [Sampo Sikali (Cikali)] dan saudara perempuan isteri/ suami (Iparaq) (Ibid., hal. 74-76). Dalam hal sistem kepercayaan pun, beberapa keluarga keturunan Cina Makassar mengikuti sistem kepercayaan tradisional masyarakat Bugis atau Makassar; seperti misalnya di rumah mereka menyimpan boe-boe (patotoang) atau kalompoang atau arajang, yaitu: pakaian nenek moyang yang dikeramatkan, seperti kopiah adat (Makassar: songkoq pamiring), baju, sarung, atau dapat pula berupa senjata, seperti keris, badik, pedang (Makassar: kalewang), dan tombak, yang kesemuanya pada waktu-waktu tertentu diberi penghormatan berupa upacara pencucian, pemberian sesajian atau korban dan sebagainya. Untuk itu mereka menghadirkan pemimpin upacara yang dalam bahasa Makassar disebut 'sanro' atau 'boto' atau 'bissu' (yaitu pendeta Bugis yang berpenampilan perempuan dan memiliki kesaktian) (Ibid., hal. 9495). Mereka juga datang kepada pemimpin spiritual yang dikenal dengan nama Angku Boe untuk minta dibacakan mantra-mantra tertentu sebagai bentuk penghormatan atau pemujaan terhadap leluhur (hal. 96), di samping mendatangi makam-makam yang dikramatkan oleh orang Makassar, seperti makam orang-orang suci (wali) atau orangorang pemberani dari Kerajaan Gowa di masa lalu, antara lain Makam Syeh Yusuf yang 
terletak di Lakiung daerah perbatasan Kota Makassar dan Kabupaten Gowa. Di sana mereka, selain berziarah, juga meminta berkah (hal. 97).

Percampuran budaya semacam ini tidak hanya terjadi pada orang Cina-Makassar. Sayangnya tulisan tentang hal ini pada komunitas-komunitas Cina (Tionghoa) di tempat-tempat lain sangat terbatas, sehingga sangat sulit memberikan contoh-contoh serupa. Diperlukan studi yang lebih serius untuk mendalami hal ini. Tulisan ini tidak dimaksudkan untuk itu, melainkan hanya sebagai langkah awal untuk menggugah perhatian ke arah tersebut.

\section{PEKERJAAN/PROFESI DAN PERUBAHAN GENERASI DI KALANGAN ORANG TIONGHOA}

Selama berabad-abad, orang Cina (Tionghoa) selalu dikenal sebagai pedagang. Bahkan dalam konteks pasar modern hari ini pun, sepertinya profesi mereka tidak tampak berubah, walaupun istilah yang dipergunakan sudah mengalami perubahan. Hari ini orang Cina selalu disebutkan sebagai 'berkecimpung di dunia bisnis' yang pada prakteknya mencakup bidang perdagangan, manufaktur dan jasa. Pandangan seperti ini sangat problematik karena menafikan fakta tentang orang Tionghoa yang berprofesi sebagai guru, dosen, dokter, insinyur, petani, nelayan, pegawai negeri sipil dan tentara. Bahkan hari ini kita bisa menemukan sejumlah orang Tionghoa yang terjun ke dunia politik untuk menjadi seorang politisi. Basuki Tjahaja Purnama yang lebih dikenal sebagai Ahok adalah salah satunya' ${ }^{9}$ Sayangnya untuk saat ini sangat sulit untuk mendapatkan data statistik yang mendukung hal ini, karena data etnisitas hanya terbatas pada Sensus tahun 2000 dan 2010, dan data-data tersebut pun tidak dipublikasikan.

Kisah dr. Dede Gunawan, dokter ahli syaraf dan Kepala Bagian Saraf di Rumah Sakit Hasan Sadikin, Bandung yang diceritakan oleh Abdul Baqir Zein (2000) dalam bukunya yang berjudul Etnis Cina dalam Potret Pembauran di Indonesia, barangkali bisa memperlihatkan bahwa memang tidak semua orang keturunan Cina menjadi pebisnis. Ibu dan ayah dr. Dede di zaman Belanda adalah lulusan Hollandsch Chineesche Kweek School, yaitu sekolah guru berbahasa Belanda untuk orang Cina. Terakhir ayah dr. Dede mengajar di SMA di Gang Batu, Jakarta. Kakak dr. Dede, yaitu dr. Suryadi Gunawan, pernah bekerja di Irian Jaya selama 17 tahun sebagai dokter pertama yang dikirim pada zaman UNTEA (badan PBB untuk penyelesaian masalah Irian Barat) atau masa penyerahan kedaulatan dari Belanda kepada Indonesia. Ia menjadi Kepala Kanwil Kesehatan di sana sampai tahun 1980. Adik dr. Dede, Sulistia S.K., bekerja di bagian Farmakologi UI dan merupakan chief editor buku Farmakologi dan Terapi yang dianggap salah satu buku standar dalam bidang kedokteran di Indonesia (hal. 67).

\footnotetext{
9 “Biografi Ahok (Basuki Tjahaja Purnama)”, http://biografi.rumus.web.id/2012/05/biografi-ahok-basuki-tjahajapurnama.html, diakses tanggal 14 Agustus 2012.
} 
Kisah Sofyan Tan di Medan juga menarik untuk dipaparkan di sini. Ia adalah seorang dokter, akan tetapi ia tidak mempraktekkan ilmu kedokteran yang didapatkannya. Ia malah mendirikan lembaga pendidikan yang diberi nama Yayasan Perguruan Sultan Iskandar Muda (YPSIM) di daerah Sunggal, Medan. Idenya ini bermula dari gagasan mengenai pembauran antara pribumi dan non-pribumi. Sekolah yang didirikan pada tahun 1988 itu adalah sekolah dasar (SD), namun dengan cepat berkembang sehingga mencakup SMP dan SMU. Dari awalnya hanya 200 orang siswa, sekarang sudah menjadi 1.400 siswa, namun komposisinya tetap 50-50 dari golongan keturunan Cina dan juga pribumi. Semula sekolah itu ditujukan untuk orang miskin, akan tetapi dengan mutu yang berhasil dipertahankan pada peringkat tinggi, kini orang yang berada atau kaya banyak yang mengirimkan anaknya ke Sekolah Iskandar Muda itu. Karena keunikan gagasan dan kesungguhan kerjanya, Sofyan juga mendapat banyak bantuan dari berbagai tokoh masyarakat dan pejabat negara, seperti Sarwono Kusumaatmadja dan B.J. Habibie. Sofyan sudah melebarkan usaha pembauran etnis ke arah pembauran ekonomi dan non-ekonomi di pedesaan (Zein, 2000:110-111).

Dalam catatan Shaifuddin Bahrum pun terdapat beberapa nama orang Cina Peranakan Makassar yang beraktivitas di dunia seni pada periode tahun 1990an-2000, seperti Wilson Tjandinegara yang menulis sekumpulan sajak antara lain Puisi Untukmu (1995) dan Rumah Panggung di Kampung Halaman (1999); Arif Gossin yang pernah bekerja sebagai jurnalis di Harian Pedoman Rakyat di Makassar dan banyak menulis kritik Sastra dan Budaya; dan Muh. David Aritanto yang memimpin anak asuhnya dalam sanggar teater Merdeka Makassar (Bahrum, 2003:114-115). Juga jangan dilupakan beberapa nama yang cukup terkenal di dunia sastra dan teater di Makassar tahun 1920-30an, seperti Hoo Eng Dji, seorang pencipta lagu-lagu Makassar (Ati Raja, Sailong, Dendang-dendang, dan Paqsianteng) dan Pui Tjung An, seorang musisi yang rumahnya di jalan Samalona dijadikan markas pertemuan bagi seniman musik daerah seperti Baharuddin Manjia, Ambo Tang Sijaya, Ahamd Gurua, Ridwan Dg Sarro, Giok Sukarman dan generasigenerasi selanjutnya (Aminullah Lewa, Abdullah Sijaya, Yusuf Alamudi dan Iwan Tompo) (Ibid., hal. 103 dan hal. 106).

Generasi muda Tionghoa Indonesia hari ini lebih beragam lagi dibandingkan pendahulu-pendahulu mereka, karena ada beberapa variabel lain yang perlu diperhitungkan. Salah satunya adalah variabel 'kelas'. Jika di masa lalu, pembedaan status sosial dilakukan berdasarkan profesi atau jenis pekerjaan yang dilakukan, misalnya profesi dokter lebih dihargai daripada profesi petani atau nelayan, hari ini kita melihat adanya, pertama, kelompok generasi muda Tionghoa 'elit' yang merupakan generasi kedua 'pemilik' dari kerajaan-kerajaan bisnis orang Tionghoa yang berkembang pada masa Orde Baru (misalnya Anthony Salim dari Salim Group, James Riady dari LIPPO Group, dan seterusnya); kedua, generasi muda Tionghoa 'kelas menengah atas' yang merupakan lulusan perguruan tinggi di luar negeri (Amerika, Australia, Jerman, 
Singapura, dan sebagainya) yang pada umumnya bergerak dalam bidang jasa teknologi (desain, advertising, computer programer, dan lain-lain), baik sebagai staf tingkat tinggi maupun sebagai partner usaha dalam suatu joint-partnership; ketiga, generasi muda Tionghoa 'kelas menengah' yang merupakan generasi terdidik di dalam negeri (Indonesia) yang tersebar dalam berbagai bidang pekerjaan dari arsitektur sampai pada bidang obat-obatan, dan ke empat, generasi muda Tionghoa Indonesia yang tidak melanjutkan ke perguruan tinggi tapi langsung mengeluti dunia usaha, khususnya usaha yang sudah dirintis oleh orang tuanya (umumnya pedagang/pemilik toko); ke lima, generasi muda Tionghoa yang kurang beruntung, baik dalam bidang usaha maupun bidang pendidikan, mereka umumnya menjadi pegawai atau karyawan di toko-toko orang Tionghoa.

Barangkali kita masih bisa mengidentifikasi beberapa kelompok lagi, akan tetapi hal itu tidak terlalu signifikan bagi apa yang dibahas di sini, karena pada intinya penulis hanya ingin mengemukakan bahwa perkembangan teknologi komunikasi dan informasi telah mendiversifikasi berbagai kegiatan sosial-ekonomi menjadi sub-sub kegiatan yang spesifik, sehingga secara keseluruhan dunia usaha dan dunia kehidupan menjadi sangat kompleks. Hal ini selanjutnya berdampak pada stratifikasi sosial di antara kelompokkelompok di dalam masyarakat, termasuk pada komunitas Tionghoa Indonesia.

\section{KATA PENUTUP}

Masalah heterogenitas orang Tionghoa Indonesia seringkali dilihat sebagai sesuatu yang sederhana, karena cara pandang yang umum cenderung terfokus pada katagorisasi tradisional, seperti suku bangsa, agama dan pekerjaan. Padahal, dalam katagori-katagori tersebut pun kita bisa melihat munculnya varian-varian baru akibat perkembangan zaman yang didukung oleh perkembangan teknologi. Tulisan ini bukan merupakan hasil studi yang komprehensif untuk mengangkat hal tersebut. Penulis harap di masa depan akan ada hasil studi yang lebih sistematis yang dapat memberitahukan kepada kita detail-detail yang lebih menarik.

\section{REFERENSI}

Bahrum, Shaifuddin. Cina Peranakan Makassar: Pembauran Melalui Perkawinan Antarbudaya, Makassar: Yayasan Baruga Nusantara. 2003.

Hebron, J.L. "In Diaspora", dalam Wang Ling-Chi \& Wang Gungwu (eds.), The Chinese Diaspora: Selected Essays, Volume II, Singapore: Eastern University Press, hal. xiixv. 2003.

Mackie, J.A.C. dan Charles A. Coppel. "A Preliminary Survey", dalam J.A.C. Mackie (editor), The Chinese in Indonesia: Five Essays, Melbourne: Thomas Nelson LTD in association with The Australian Institute of International Affairs, hal. 1-18. 1976.

Susanto, Andreas A. "Socio-Cultural Accommodation", dalam Michael R. Godley 
\& Grayson J. Lloyd (editors), Perspectives on the Chinese Indonesians, Adelaide: Crawford House Publishing Pty Ltd, hal. 183-2002. 2001.

Wang, Gungwu. "'Are Indonesian Chinese unique?': Some Observations", dalam J.A.C. Mackie (editor), The Chinese in Indonesia: Five Essays, Melbourne: Thomas Nelson LTD in association with The Australian Institute of International Affairs, hal. 199-210. 1976.

Wang Ling-Chi. "On Luodi-shenggen”, dalam Wang Ling-Chi \& Wang Gungwu (eds.), The Chinese Diaspora: Selected Essays, Volume II, Singapore: Eastern University Press, hal. ix-xi. 2003.

Wang Ling-Chi \& Wang Gungwu. "Preface", dalam Wang Ling-Chi \& Wang Gungwu (eds.), The Chinese Diaspora: Selected Essays, Volume II, Singapore: Eastern University Press, hal. vi-viii. 2003.

Jahja [baca: Yahya), H. Junus. Masalah Tionghoa di Indonesia: Asimilasi vs Integrasi, Jakarta: Lembaga Pengkajian Masalah Pembauran. 1999.

Zein, Abdul Baqir. Etnis Cina dalam Potret Pembauran di Indonesia, Jakarta: Prestasi Insan Indonesia. 2000. 